\title{
SEASONAL VARIATION ON PHYSIOCHEMICAL PARAMETERS AND MACROPHYTES PRODUCTION OF RUPA LAKE, KASKI, NEPAL
}

\author{
D. Kunwar and A. Devkota
}

\section{ABSTRACT}

The Rupa lake is the third largest and heavily tampered lake of Pokhara Valley. Physiochemical parameters like, water temperature, $\mathrm{pH}$, dissolved oxygen (DO), total nitrogen (TN) and $\mathrm{PO}_{4}-\mathrm{P}$ and biomass of aquatic macrophytes were analyzed during pre and post-monsoon. Biomass ranged from $27.25 \mathrm{~g} / \mathrm{m}^{2}-389.25 \mathrm{~g} / \mathrm{m}^{2}$ throughout the experimental period and the highest biomass was observed during post-monsoon period. Regarding the growth form, the highest biomass was represented by emergents $\left(251.16 \pm 95.16 \mathrm{~g} / \mathrm{m}^{2}\right)$ and lowest biomass by submerged species $\left(48.39 \pm 7.27 \mathrm{~g} / \mathrm{m}^{2}\right)$. The lake can be categorized as eutrophic.

Key words: eutrophication, biomass, limnology, Rupa lake, Nepal

\section{INTRODUCTION}

Wetlands are lands transitional between terrestrial and aquatic system where soil is frequently waterlogged, the water table is usually at or near the surface or the land covered by shallow water (Podder et al. 2001). They are among the most beautiful, tranquil and productive places on earth. Nepal is home to a wide range of wetlands situated in diverse climates, stretching from mountain condition near the Himalayas in the north to tropical condition in the south. The total area occupied by wetlands has been estimated to be 382,700 ha covering approximately $2.6 \%$ of total land area of Nepal (GN/MFSC 2009). Out of the total wetland area 34,455 ha have been designated as Ramsar sites of which $68.2 \%$ area is in Tarai,31.6\% in High Mountains and about $1 \%$ in Mid-hills.

Quality of an aquatic ecosystem is dependent on the physical and chemical qualities of water as well as biological diversity within the system. The rate at which the green plants produce biomass or store energy is referred to as primary productivity. Primary productivity of an ecosystem gives the quantitative details regarding energy fixation and its availability to support bioactivity of the total system (Goldman 1968). Macrophytes generally confine themselves to the shallow zone of the aquatic ecosystem and contribute significantly to the total primary production and accelerate eutrophication (Adani and Yadav 1985). Sculthorpe (1967) and Hutchinson (1975) showed that the aquatic macrophytes influence the physiochemical parameters of littoral shallow water. The physiochemical parameters influence the aquatic macrophyte distribution. Therefore, the best way to identify the status of lake is measurement of physiochemical parameters and biomass of aquatic macrophytes.

Though the study on various aspects of Rupa Lake has started since late 1970s (Swar 1980, Nakanishi et al. 1988, Jones et al. 1989, Kafle 2000) and annual water quality analysis by Fisheries Research Centre (FRC), Pokhara; but seasonal variation on limnological parameter and its relationship with macrophyte biomass has not been carried till now. Therefore this 
study is aimed to assess the relationship between macrophyte biomass and water quality on seasonal basis.

\section{STUDY AREA}

The Rupa lake lies in Lekhnath Municipality but part of its eastern and north eastern side touches the outskirts of Rupakot VDC. It is the third largest lake of Pokhara valley and is heavily tampered and disturbed by local people. The lake is situated at an elevation of $600 \mathrm{~m}$ above the sea level with an area of 135 ha (Rai et al. 1996) and average depth of $3 \mathrm{~m}$. The lake is elongated from N-S having zigzag outline. Talbesi khola is the only feeder stream of the lake. It has a single outlet Tal khola which join stream Kotre. The occurrence of 450 different species of flora and fauna reveals its rich biodiversity (Oli 1996). Commonly occurring aquatic macrophyte are Trapa quadrispinosa, Trapa bispinosa, Nelumbo nucifera, Eichornia crasssipes and Ceratophyllum demersum (Oli 1996). Similarly the lake is abode to wide variety of migratory birds. Ferro and Swar (1980) recorded 22 major fish species.

\section{MATERIALS AND METHODS}

The comprehensive field study was carried out in pre-monsoon (May-June) and post-monsoon (October) period in 2009. Water samples were collected at a depth of one meter from the surface in cleaned bottles, in triplicate from four different sides (north, east, west, south).Water temperature and $\mathrm{pH}$ were measured in the spot. Dissolved Oxygen (DO) was measured by Winkler's method following Zobel et al. (1987) at Fisheries Research Centre laboratory, Pokhara. Total nitrogen and phosphate $\left(\mathrm{PO}_{4}-\mathrm{P}\right)$ were analyzed by following Trivedy and Goel (1986) in water engineering laboratory, Kathmandu. At each side of lake (north, east, west, south) two long imaginary transects $(30 \mathrm{~m})$ at $10 \mathrm{~m}$ apart were made from shoreline to the centre and series of quadrat $(1 \mathrm{~m} \times 1 \mathrm{~m})$ were plotted at $1.5 \mathrm{~m}$ interval. From each quadrat one-fourth $(1 / 4)$ biomass was collected in separate bags. Altogether 160 biomass samples ( 80 during each experimental period) representing different growth form; emergent, submerged and rootedfloating were taken. The collected biomass samples were oven dried at $72^{\circ} \mathrm{C}$ for 48 hours and their respective dry weight was measured by electric balance. Biomass was determined by harvest method following Zobel et al. (1987).

\section{RESULTS AND DISCUSSION}

\section{Physiochemical Characteristics of Water}

Physiochemical characteristics of water of Rupa lake varied seasonally (Table 1). Seasonal variation in water temperature was found to be related with corresponding change in atmospheric temperature (Kundangar et al. 1996). The present study did not show considerable change in water temperature from previous studies by Nakanishi et al. (1988), Rai et al. (1996) and Kafle (2000) in Rupa lake.

Hydrogen ion concentration $(\mathrm{pH})$ is the measure of the acidity and alkalinity. In the present study, $\mathrm{pH}$ value was observed lower in pre-monsoon period $(5.67 \mathrm{mg} / \mathrm{l})$ than the post-monsoon period $(6.29 \mathrm{mg} / \mathrm{I})$ (Table 1). The range of $\mathrm{pH}$ differences might be attributed to the precipitation of calcium carbonate by the planktons as reported by Bastola (1995) in Begnas lake of Pokhara. Wetzel (1983) considered that the range of $\mathrm{pH}$ of the majority of open lakes were 
6-9 and most of these lakes are bicarbonate type and favorable for the aquatic inhabitation. The $\mathrm{pH}$ value was slightly acidic in nature.

Table 1. Average limnological value of Rupa lake in two seasons.

\begin{tabular}{|l|l|l|l|l|}
\hline SN & Parameters & Pre-monsoon & Post-monsoon & Average \\
\hline 1. & Temperature $\left({ }^{\circ} \mathrm{C}\right)$ & $23.24 \pm 1.20$ & $21.90 \pm 2.10$ & $22.57 \pm 1.50$ \\
\hline 2. & $\mathrm{pH}(\mathrm{mg} / \mathrm{l})$ & $5.67 \pm 0.25$ & $6.29 \pm 0.16$ & $5.98 \pm 0.20$ \\
\hline 3. & Dissolved oxygen $(\mathrm{DO})$ & $4.16 \pm 1.10$ & $7.68 \pm 1.50$ & $5.92 \pm 1.30$ \\
\hline 4. & Total Nitrogen $(\mathrm{mg} / \mathrm{l})(\mathrm{TN})$ & $0.184 \pm 0.05$ & $0.108 \pm 0.00$ & $0.146 \pm 0.02$ \\
\hline 5. & $\mathrm{PO}_{4}-\mathrm{P}(\mathrm{mg} / \mathrm{l}) \pm$ & $0.005 \pm 0.001$ & $0.002 \pm 0.00$ & $0.004 \pm 0.00$ \\
\hline
\end{tabular}

Note: Results presented in the table represent the mean value $(n=12)$.

Source: Field Study, 2009

Dissolved Oxygen is one of the most important parameter in water quality assessment and depends upon the physiochemical and biological activities of water bodies. DO was drastically depleted in pre-monsoon period $(4.16 \pm 0.39 \mathrm{mg} / \mathrm{I})$ and increased in post-monsoon $(7.68 \mathrm{mg} / \mathrm{l})$ (Table 1) when the macrophyte community began to decompose. It shows negative correlation with $\mathrm{TN}$ and $\mathrm{PO}_{4}-\mathrm{P}$ (Table 2). Low $\mathrm{DO}$ in pre-monsoon might be due to higher water temperature and vigorous decomposition of autochthonous and allochthnous organic matter brought in by inflowing streams in warm temperature as suggested by Badge and Verma (1985). Kafle (2000) also expressed similar views in Rupa lake.

Nitrogen occurs in the aquatic system both as a result of the bacterial oxidation of atmospheric nitrogen and from the decomposition of organic matter in the lake (Lind 1974). The higher value of total nitrogen during pre-monsoon period $(0.184 \mathrm{mg} / \mathrm{l})$ (Table 1$)$ might be due to high microbial activity and excretory products of aquatic animal. Similarly low value during post-monsoon period might be due to inactiveness of microbes when decomposition rate becomes low or may also be due to dilution of water bodies after monsoon. Similar views were expressed by Kafle (2000) in Rupa Lake, Adhikari (2002) in Khaste and Dipang lake and Simkhanda (2003) in Gaindahawa lake.

Phosphorus has been considered as the main nutrients for the productivity of aquatic ecosystem. It occurs in both organic and inorganic form. It is the important nutrient essential to all biotic community present in an aquatic ecosystem (Lind 1974). During the present study higher $\mathrm{PO}_{4}-\mathrm{P}$ value during pre-monsoon period $(0.005 \mathrm{mg} / \mathrm{l})$ might be due to high concentration of Zooplankton excreta and surface run off from adjacent agricultural land fertilized with phosphate and rapid bacterial metabolism as indicated by Heron (1961). The lower value during post monsoon period $(0.002 \mathrm{mg} / \mathrm{I})$ might be due to rapid biological uptake and the formation of water insoluble calcium carbonate (Zutshi and Vass 1973, Zutshi and Khan 1977). The lake can be categorized as eutrophic based on $\mathrm{PO}_{4}-\mathrm{P}$ as suggested by Forsberg and Ryding (1980). 
Table 2. r-value obtained from Karl Pearson correlation co-efficient between different ecological attributes.

\begin{tabular}{|l|l|l|l|l|l|}
\hline Attributes & Water temp. & $\mathbf{p H}$ & $\mathbf{D O}$ & TN & PO $_{4}-\mathbf{P}$ \\
\hline Biomass & -0.699 & 0.561 & $0.873^{* *}$ & $-0.834^{* *}$ & $-0.879^{* *}$ \\
\hline Water temp. & - & -0.678 & $-0.883^{* *}$ & 0.607 & $0.939^{* *}$ \\
\hline pH & - & - & $0.820^{*}$ & $-0.809^{*}$ & -0.698 \\
\hline DO & - & - & - & $-0.877^{* *}$ & $-0.958^{* *}$ \\
\hline TN & - & - & - & - & $0.747^{*}$ \\
\hline
\end{tabular}

* Correlation is significant at the $p=0.05$ level (2-tailed)

** Correlation is significant at the $p=0.01$ level (2-tailed)

\section{Productivity Estimation of Aquatic Macrophytes}

During the present study it was observed that more than 60 percent of the lake was covered by aquatic macrophytes creating an appearance of a swamp land. The major macrophytes flora in study area were Trapa quadrispinosa. Hydrilla verticillata, Leersia heandra and Nelumbo nuciflora. The dry weight value of aquatic macrophytes ranged from $27.25 \mathrm{~g} / \mathrm{m}^{2}$ to $389.25 \mathrm{~g} / \mathrm{m}^{2}$ throughout the experimental period. The maximum dry weight value during the post-monsoon and pre-monsoon period was $389.25 \mathrm{~g} / \mathrm{m}^{2}$ and $228.28 \mathrm{~g} / \mathrm{m}^{2}$, respectively (Fig.1). Similar results were demonstrated by Sankhala and Vyas (1982), in moist bank community of Bangela tank in Udaipur, India, in which they recorded maximum biomass $\left(315.8 \mathrm{~g} / \mathrm{m}^{2}\right)$ in October and minimum in April $\left(132 \mathrm{~g} / \mathrm{m}^{2}\right)$. Similar trend of biomass production was also recorded by Kaul et al. (1978) in Kashmir lakes, India, and Acharya (1996) in Ghodaghodi tal, Nepal. The major cause of macrophytic growth in the lake could be attributed to the large amount of influx of fertilizers from the adjoining cultivated land, and surface run off which brings large amount of litter from the catchment areas having dense forest.

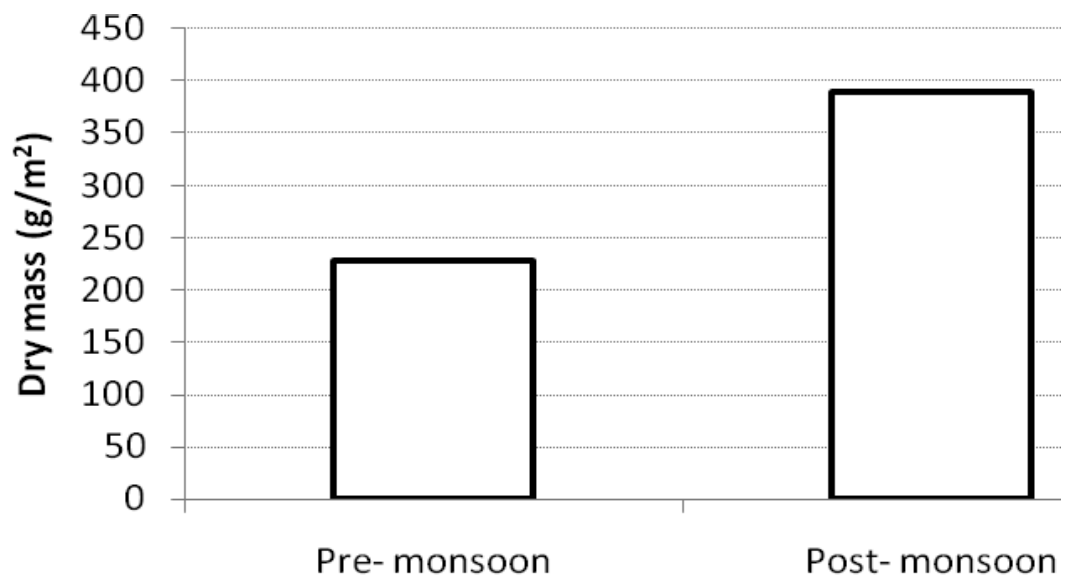

Seasons

Figure1. Seasonal total productivity of aquatic macrophytes in Rupa lake. 
Shallower areas near the shoreline were found to be more productive than the deeper zone of the lake. The low productivity of submerged species can be attributed to their lower photosynthetic rate because of their incapability to utilize incident solar radiation coupled with other detrimental environmental condition (Miller 1978). The major dominating macrophytes flora in study area representing different growth forms were Leersia heandra, Nelumbo nuciflora, Trapa quadrispinosa, Rotala rotundifolia, Nymphoides indica and Hydrilla verticillata. According to growth form, highest biomass was recorded for emergent species $\left(251.16 \mathrm{gm} / \mathrm{m}^{2}\right)$, followed by rooted floating $\left(134.76 \mathrm{gm} / \mathrm{m}^{2}\right)$ and submerged species $\left(48.39 \pm 7.27 \mathrm{~g} / \mathrm{m}^{2}\right)($ Fig. 2). The result agrees with the idea of Sharma (1995) in Kawar Lake, India, and Whittaker and Likens (1975), who stated that emergent macrophyte of littoral wetlands in the shore regions of lakes, are among the most productive habitat of biosphere.

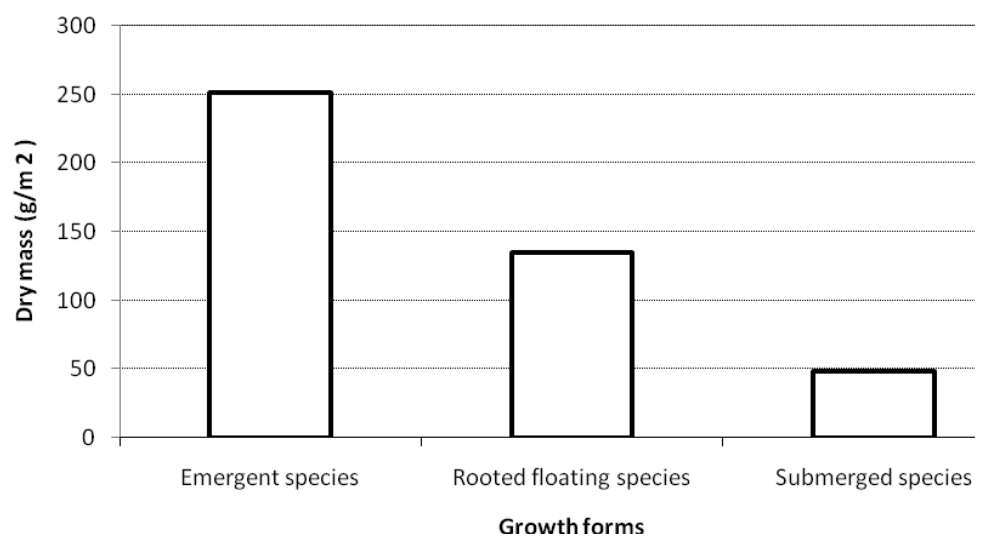

Figure 2. Total average above ground biomass according to growth form.

The highest biomass of $151.16 \mathrm{~g} / \mathrm{m}^{2}$ in eastern side of the lake (Fig. 3) might be due to high nutrient load that might have leached from the surrounding agricultural land, shallowness and anthropogenic disturbances. Similarly, the highest biomass value recorded by the emergents might be due to their high photosynthetic rate because of exposed condition in fertile soil and better utilization of nutrients.

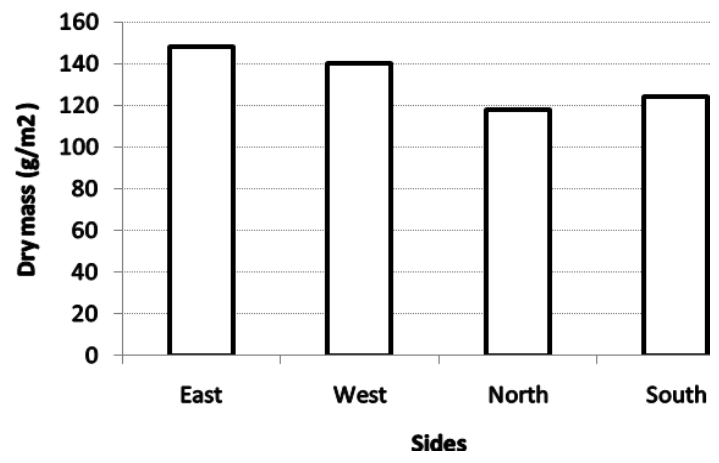

Figure 3. Total average above ground biomass in different sides of the lake. 
In freshwater ecosystem, macrophyte biomass and water quality are intricately related. Aizaki (1985) stated that trophic status of lake lies on phytoplankton number and water quality. The research findings reveals that biomass positively correlated with $\mathrm{pH}(\mathrm{r}=0.560)$ and $\mathrm{DO}(\mathrm{r}=$ 0.873 ) (Table 2), but it is negatively correlated with total nitrogen $(r=-0.834, p=0.01)$ and $\mathrm{PO}_{4}-\mathrm{P}(\mathrm{r}=-0.879, \mathrm{p}=0.01)$ (Table 2). Kafle (2000) also obtained negative correlation between biomass and total nitrogen in lake Phewa and Rupa. The result showed that macrophyte biomass and nutrient content of Lake were inversely related. The higher biomass in post-monsoon period was accompanied by low water nutrient value and low biomass during pre-monsoon was accompanied by high nutrient value of water.

There is a seasonal variation in physiochemical parameters and biomass of aquatic macrophytes. The highest biomass was observed during post monsoon period. Regarding the growth form, the highest and lowest biomass was represented by emergents $\left(251.16 \pm 95.16 \mathrm{~g} / \mathrm{m}^{2}\right)$ and submerged species $\left(48.39 \pm 7.27 \mathrm{~g} / \mathrm{m}^{2}\right)$ respectively. The lake can be categorized as eutropic.

\section{ACKNOWLEDGEMENTS}

Authors like to express sincere gratitude to Prof. Dr. Krishna Kumar Shrestha, former Head, Central Department of Botany, for providing valuable laboratory facilities and Prof. Dr.Mohan Siwakoti and Bharat Babu Shrestha Central Department of Botany, for providing valuable suggestions. We are also indebted to Fisheries Research Center (FRC), Pokhara, for providing laboratory facilities. Sincere thanks also go to Mr. Dinesh Thapa for his kind help during field study.

\section{REFERENCES}

Acharya, P.,1996. Wetlands vegetation and its utilization in Ghodaghodi and Nakhrodi Tal, Kailali, Nepal. M.Sc. Dissertation Submitted to Central Department of Botany, Tribhuvan University, Kathmandu, Nepal.

Adani, A.D. and M. Yadav,1985. Chemical and productional characteristics of Potamogeton pectinatus (Linn.) and Hydrilla verticillata (Royle.) In Adani, A.D. (ed) An eutrophic lake. Proc. Nat. Symp. Pure and Applied Limnology. Bulletin Botanical Society, 32:96-105.

Adhikari, A., 2002. Ecological study and environmental management of Khaste and Dipang Lake: Wetlands of Pokhara Valley, Kaski, Nepal. M.Sc. Dissertation Submitted to Central Department of Botany, Tribhuvan University, Kathmandu, Nepal.

Aizaki, B.M.,1985. Trophic status and water quality of high altitude lakes in Mt. Annaupurna region, microb expedition Japan, pp 14-26.

Badge, U.S. and A.K. Verma,1985. Limnological studies on J.N.U. Lake, New Delhi, India, Bull. Bot. Soc. Sagar, 32:16-23.

Bastola, S.C.,1995. Study of abiotic and biotic environment of Begnas lake in Kaski district. M.Sc. Dissertation submitted to Central Department of Zoology, T.U., Kathmandu.

Ferro,W. and D.B. Swar, 1978. Bathymetric maps from three lakes in Pokhara valley, Kaski, Nepal, Journal of Science and Technology, 1:177-188.

Forsberg, C. and S.O. Ryding,1980. Eutrophication parameters and trophic state indices in 30 
Swedish waste receiving lakes Arch. Hydrobiologia, 89:189-207.

GN/MFSC, 2009. Nepal Fourth National Report to the Convention on Biological Diversity. The Ministry of Forest and Soil Conservation, Kathmandu, Nepal.

Goldman, C.R.,1968. Aquatic primary production. American Zooplankton, B(i): 31-42.

Heron, J.,1961. Phosphorus adsorption by lake sediments. limnology and Oceanogr., 6: 338.

Hutchinson, G.E.,1975. A treatise on limnology Vol.3. New York, Wiley.

Jones, J.R., M.F. Knowlton and D.B.Swar.,1989. Limnological reconnaissance of water bodies in central and southern Nepal. Hydrobilogia, 184:171-189.

Kafle, R.R., 2000. Growth and clump maintenance of Trapa quadrispinosa Roxb. in response to physico-chemical parameters of Phewa and Rupa lakes, Pokhara, Kaski, Nepal. M.Sc. Dissertation Submitted to Central Department of Botany, Kirtipur, Kathmandu, Nepal.

Kaul, V., C.L. Trisal and J.K. Handool.,1978. Distribution and production of macrophytes in some aquatic bodies of Kashmir. In Glimpses of ecology. Int. Sci. Publs., Jaipur, India, pp 313-334.

Kundangar, M.R., D. Sarwar and J. Hussain,1996. Zooplankton population and nutrient dynamics of wet lands of Wular Lake, Kashmir India. In Jha, P. K., G.P.S. Ghimire, S.B. Karmacharya, S.R. Baral and P. Lacoul (eds) Enviroment and biodiversity: In the context of south Asia. Ecological society (ECOS), Kathmandu, Nepal, pp 128-134.

Lind, O.T.,1974. Handbook of common methods in limnology. C.V. Mosby Co. Saint Louis, USA,199 p.

Miller, J.B.,1978. Vegetation changes in shallow marsh wetlands under improving moisture regime. Canandian Journal of Botany, 51:1443-1457.

Nakanishi, M., M.M. Watanabe, A. Terashima, Y. Sako, T. Konda, K. Shrestha, H.R. Bhandari and $Y$. Ishida,1988. Studies on some limnological variables in subtropical lakes of the Pokhara Valley. Kaski, Nepal. Japanese Journal of Limnology, 49(2):71-86.

Oli, KP.,1996. An environmental study of Nepal's Begnas and Rupa Lakes. NPC/IUCN, National conservation strategy implication project.

Podder, P., A.M. Puste and K.S. Gupta, 2001. Wetlands and their agronomic utilization. In Jha, P.K., S.R. Baral, S.B. Karmacharya, H.D. Lekhak, P. Lacoul and C.B. Baniya (eds) Evironment and agriculture: Biodiversity, agriculture and pollution in south Asia. Ecos, Kathmandu, Nepal, pp 410-413.

Rai, A.K., R.M. Mulmi and R.P. Dhakal,1996. Production assessment of planktivarous fish species in relation to seasonal changes in plankton population in lake of Pokhra Valley. In Annual Technical Report (1994-95). Nepal Agriculture Research Centre, FRC, Pokhara, pp 1-15.

Sankhala, S.K. and L.N. Vyas,1982. Observations on the moist blank community of Banghela Tank, Udaipur, India. In Gopal, B., R.E. Turner, R.G. Welzel and D.F. Whishman (eds) Wetland ecology and management. International Scientific Publications, Jaipur, India, pp 197-207.

Sculthorpe, C.D.,1967. The biology of aquatic vascular plants. Edward Arnold (Publishers) Ltd., 
London, $610 \mathrm{p}$.

Sharma, U.P.,1995. Ecology and management of Kawar lake: A major tropical wetland of southeast Asia, Bhagalpur, India. Sharma, U.P. and J.S.D. Monshi (eds).

Simkhada, D., 2003. Ecology and management issues of Gaindahawa lake, Rupandeni, Nepal. M.Sc. Dissertation Submitted to Central Department of Botany, Tribhuvan University, Kathmandu, Nepal.

Swar, D.B.,1980. Present status of limnological research in Nepal. In Proceedings of first workshop for the promotion of limnology in Developing countries, Kyoto, Japan.

Trivedy, R.K. and P.K. Goel,1986. Chemical and biological methods for water pollution studies. Environment Publications, Karad, India.

Wetzel, R.G.,1983. Limnology. Saunders College Publishing, USA (2nd edition).

Whittaker, R.H. and G.E., Likens, 1975. The biosphere and man. In H. Leith and R.H. Whitaker (eds) Primary productivity of the biosphere. Springer Verlag. New York.

Zobel, D.B., P.K. Jha, M.J. Behan and U.K.R. Yadav,1987. A practical manual for ecology. Ratna Book Distributors, Kathmandu, Nepal.

Zutshi, D.P. and K.K. Vass,1973. Limnological studies on Dal lake: Chemical features. India , Journal of Ecology, 5(1):90-97.

Zutshi, D.P. and M.A. Khan,1977. Limnological investigations of two subtropical lakes, Geobios. 4:45-58.

\section{AUTHOR'S ADDRESS}

\section{Devendra Kunwar and Anjana Devkota}

Central Department of Botany, Tribhuvan University, Kathmandu, Nepal

(email: devkotaa@gmail.com) 